\title{
KODE ETIK JURNALISTIK DALAM PRAKTIK FOTO- JURNALISME: KASUS KAMPANYE PEMILIHAN PRESIDEN 2009 DI INDONESIA
}

\author{
Ririt Yuniar \\ Program Studi Pengkajian Seni Pertunjukan dan Seni Rupa \\ Sekolah Pascasarjana Universitas Gadjah Mada \\ Irwan Abdullah, G.R. Lono Lastoro Simatupang \\ Jurusan Antropologi Budaya Fakultas Ilmu Budaya Universitas Gadjah Mada \\ Timbul Haryono \\ Jurusan Arkeologi Fakultas Ilmu Budaya Universitas Gadjah Mada
}

\begin{abstract}
Journalistic photos appear in newspapers for news purposes. In many cases, many parties are interested in using the mass media for their own vested interests. The photos of the Presidential and VicePresidential candidates in the 2009 Indonesian election were examples of such uses. These photos contained symbols which were manipulated and presented in the public sphere. Hence, these photos also reflected power relations within Indonesian society, a society which is full of individual interests.

This study attempts to show how the photojournalism appearing in the media during the 2009 election time was intensively used by the candidates, who were also the capital backers. The photos were not presented as they were, but rather composed upon the candidates' request for the purposes of image building. For several reasons, including media survival in the global era and its heavy competition and pragmatic motivations, some media have shown a loss of "independency." This study also shows that journalistic photos record the existence of values and interests of those appearing on newspaper. The 2009 Presidential and Vice Presidential campaign in Indonesia, one framed in photojournalism, is a social reality analogous to social theatre or a theatrical performance.
\end{abstract}

Keywords: Code of Ethics, Journalistic Photo, Campaign of Election of the President, Indonesia

\begin{abstract}
ABSTRAK
Foto-foto jurnalistik hadir dalam media cetak (koran) untuk sebuah pemberitaan. Dalam banyak kasus, disadari atau tidak, ada pihak-pihak yang berkepentingan menggunakan media sebagai kendaraan untuk mencapai tujuan tertentu. Hal itu tampak pada foto-foto calon presiden pada pemilu 2009 yang merefleksikan simbol-simbol yang diangkat, 'dimanipulasi', dan kemudian dihadirkan ke publik. Di samping itu, foto tersebut merefleksikan hubungan kekuasaan dalam suatu masyarakat yang sarat dengan kepentingan-kepentingan.

Studi ini ditunjukkan bahwa foto jurnalistik telah dimanfaatkan secara intensif oleh pemilik modal yang juga calon-calon presiden dan wakil presiden. Foto-foto mereka tidak ditampilkan apa adanya dalam surat kabar, tetapi dikomposisikan sesuai dengan tujuan dan citra yang ingin dibangun oleh para calon. Dalam tekanan kelangsungan hidup media yang berat, dan dalam dunia yang berubah menjadi lebih pragmatis, serta kompetisi yang semakin ketat antarmedia, maka media secara perlahan kehilangan sifat "independennya". Media hidup dari pesanan-pesanan dan dari hal-hal yang sederhana berupa iklan hingga pesanan nilai, dan kepentingan yang diusung oleh hadirnya suatu surat kabar. Dengan demikian, foto sebagai media mampu merekam serangkaian nilai dan kepentingan. Kampanye pemilihan presiden 2009 yang dibingkai dalam foto merupakan realitas sosial yang tampak analog dengan drama sosial dan dengan suatu performance.
\end{abstract}

Kata Kunci: Kode Etik, Foto Jurnalistik, Kampanye Pemilihan Presiden, Indonesia 


\section{PENGANTAR}

Foto-foto jurnalistik hadir dalam media cetak (koran) untuk sebuah pemberitaan. Dalam banyak kasus, disadari atau tidak, ada pihak-pihak yang berkepentingan menggunakan media sebagai kendaraan untuk mencapai tujuan tertentu. Hal itu dikarenakan media mempunyai kekuatan untuk menaikkan citra positif seseorang di tengah masyarakat luas. Visualisasi tokoh dalam berbagai format foto jurnalistik saat kampanye pemilihan presiden, misalnya, telah menjadi instrumen penting yang memperlihatkan betapa sentralnya peranan foto jurnalistik di dalam-nya. Melalui foto jurnalistik, tokoh dan partai dihadirkan dengan apik serta dibungkus secara rapi dengan satu tujuan, yakni me-narik massa konstituen atau pemilik suara (voter preference) sebanyak-banyaknya. Lewat foto itu juga mereka membentuk opini publik akan pihak yang paling benar dan paling pantas dipilih untuk memimpin negara.

Goffman meletakkan realitas politik seperti di atas dalam kerangka performance studies. Ia menjelaskan, bahwa kehidupan sosial politik dapat dipahami sebagai rangkaian pertunjukan yang terkait pada suatu pemahaman bahwa yang paling terlihat tentang kehidupan manusia terletak pada bagaimana kita melihat yang tampak di permukaan (Schechner, 2002: 175). Pemikiran Goffman itu menarik untuk alat analisa dalam studi foto jurnalistik pada kampanye pemilihan presiden 2009 di Indonesia.

Studi ini mengkaji foto pemilu presiden 2009 sebagai sign yang merefleksikan dua hal. Pertama, foto merupakan refleksi nilainilai dalam simbol-simbol yang diangkat dan 'dimanipulasi' serta dihadirkan ke publik. Kedua, refleksi hubungan kekuasaan dalam suatu masya-rakat yang sarat dengan kepentingan-kepentingan. Dengan cara ini diharapkan akan diperoleh pemahaman tentang bagaimana foto sebagai media mampu merekam serangkaian nilai dan kepentingan, dan menjadi landasan dalam penataan sosial yang lebih baik.

Tidak hanya persoalan teknis permukaannya saja, tetapi juga kedalaman mak- na yang berkaitan dengan elemen pendukung reproduksi seperti nilai-nilai ataupun latar belakang media baik secara ideologi maupun kreativitas fotografer, menjadi elemen pembentuk reproduksi tersebut. Perhatian pada pose, pencahayaan, setting latar layaknya persiapan sebuah pertunjukan (performance) dilakukan oleh politisi dan fotografer. Foto jurnalistik kampanye pemilu yang mengangkat realitas kehidupan itu juga dapat dikatakan sebagai performance. Kampanye pemilihan presiden sebagai realitas sosial yang dianalogikan sebagai drama sosial ini merupakan suatu performance yang dibingkai dalam bentuk foto jurnalistik.

Foto jurnalistik sebagai karya visual mampu merekam atau mengabadikan sebuah peristiwa atau realitas yang dibingkai (frame) dengan nilai, estetika dan etika fotografi. Proses pembing-kaian (framing) membuktikan bahwa suatu peristiwa itu benarbenar terjadi dalam suatu kerangka kultural dan struktural yang sangat mempengaruhi pembentukan maknanya. Hadirnya suatu foto bukan hanya sebagai sebuah produk, tetapi juga sebagai suatu konstruk yang di dalamnya termuat berbagai gagasan dan nilai yang dapat menjadi petunjuk tentang keberadaan dan berlakunya sesuatu dalam suatu masyarakat. Kajian atas foto kemudian memberikan peluang yang terbuka bagi pemahaman yang saksama tentang suatu gejala sebagai constructed reality.

\section{PEMBAHASAN \\ Kontroversi Idealisme vs Komersial}

Tidak dapat dipungkiri bahwa keberadaan suatu media sangat terikat pada sumber pembiayaan. Beberapa media mengalami kesulitan yang tidak jarang telah berujung pada kesejahteraan karyawan yang rendah yang menciptakan iklim kerja yang berbeda. Sumber finansial ini pula yang menentukan orientasi dari media karena perbedaan tentang idealisme dan pragmatisme dimulai dari sini. Pentingnya modal bagi keberlangsungan hidup koran dan media massa, ternyata juga memainkan peran dalam mempengaruhi pemberitaan yang dimuat di koran bersangkutan. 
Menurut Bourdieu, modal yang mencakup hal-hal material dan simbolik berperan sebagai sebuah relasi sosial yang terdapat di dalam suatu sistem pertukaran, yang kemudian merepresentasikan dirinya sebagai sesuatu yang jarang dan layak untuk dicari dalam formasi sosial tertentu. Modal, lanjut Bourdieu, merupakan basis dominasi. Beragam jenis modal dapat ditukar dengan jenis modal lainnya, sehingga modal juga bersifat 'dapat ditukar'. Penukaran paling hebat yang telah dibuat adalah penukaran pada modal simbolik, sebab dalam bentuk inilah bentuk-bentuk modal yang berbeda dipersepsi dan dikenali sebagai sesuatu yang $l e-$ gitimate. Agar dapat dipandang sebagai seseorang atau kelas yang berstatus dan memiliki prestise, berarti ia juga harus diterima sebagai sesuatu yang legitimate, dan terkadang sebagai otoritas yang legitimate. Posisi semacam itulah yang kemudian membawa serta kekuasaan untuk memberi nama (untuk kelompok tertentu), kekuasaan untuk mewakili kesepakatan umum (common sense), dan yang terpenting adalah kekuasaan untuk menciptakan 'versi dunia sosial yang resmi' (Bourdieu, 1985).

Peran pasar dan pemilik modal dalam pemberitaan seputar kampanye capres 2009 secara gamblang terungkap dalam focus group discussion (FGD) di kantor Antara pada 5 Agustus 2010. Seorang peserta dari media cetak nasional menyatakan bahwa ketika sudah mengerucut tiga tokoh, ada proses briefing untuk mengutamakan satu calon tertentu demi kepentingan institusional. Proses briefing yang dilakukan oleh atasan dan diteruskan kepada editor yang selanjutnya menugaskan wartawan dan fotografer, adalah salah satu bukti intervensi pasar dan pemilik modal terhadap content berita media terkait. Jika mereka tidak mematuhi itu, besar kemungkinan para stakeholder akan berpikir ulang untuk menanamkan modal lagi di sana.

Dengan nada yang sama, peserta lain menyatakan adanya campur tangan dan kepentingan pasar serta pemilik modal yang bermain dalam pemberitaan, sehingga para redaktur dan editor harus dengan jeli melihat mana berita yang memiliki nilai jual yang baik di antara berita yang lain. Dengan demikian tampak bahwa karakter suatu media tidak terlepas dari sumber pembiayaan media yang mengalami transformasi dari waktu ke waktu. Pada awalnya, suatu media tumbuh dengan kekuatan-kekuatan ideologis yang perlu diperjuangkan. Pada saat itu, surat kabar lebih merupakan suatu alat perjuangan untuk mencerdaskan dan menguatkan fungsi edukasi serta tumbuhnya kekuatan masyarakat sipil (civil society). Pada proses perubahan selanjutnya, surat kabar lebih sebagai alat bisnis yang nilai-nilai komersialnya telah menjiwai isi surat kabar dengan hal-hal yang bersifat pragmatis.

Sifat pragmatis yang kemudian dilekatkan pada media, tentunya tidak bisa dilepaskan dari kredo bahwa bad news is good news (berita yang buruk akan menjadi baik dan menjual bagi media). Selain dipengaruhi oleh faktor pemilik modal dan kepentingan pasar, content yang terlihat pragmatis tersebut juga bisa muncul karena pilihan media untuk bersikap aman, alih-alih bersuara keras terhadap pemerintah. Sebagai contoh, ketika pemerintah dinilai membuat sebuah keputusan yang tidak layak, ada beberapa koran yang dengan tegas langsung menunjukkan sikap kontra, namun di sisi lain, ada juga yang memilih untuk 'membungkus' ketidaksetujuan itu dengan hal yang lebih netral. Pernyataan Andre (bukan nama sebenarnya) dari The Jakarta Post (TJP), dalam hal ini menarik disimak pernyataan Andre dalam sesi FGD yang dilakukan di kantor berita Antara pada tanggal 5 Agustus 2010:

"Pengusaha-pengusaha biasanya akan merapat ke penguasa incumbent. Tapi TJP tetap memberikan sesuatu yang netral. Kita memberitakan dan menampilkan suatu foto untuk kita sampaikan ke masyarakat. Masyarakat akan membacanya dan mereka bisa melihat kita belok ke kiri atau kanan. Kalau kita netral, kita sudah pasti aman. Saat era Presiden Soeharto, TJP berita politiknya lebih aman dibandingkan media-media lokal. Kita menulis kritik terhadap Cendana, TJP aman, kare- 
na pembaca tidak terlalu banyak. Dibandingkan Media Indonesia, Kompas, Tempo atau Republika, mereka mengritik sedikit, puspen TNI langsung menelepon redaksi masingmasing."

Akan tetapi Andre tidak menampik bahwa pengusaha dan eks-patriat - selaku pembaca TJP - akan lebih memilih dekat kepada penguasa incumbent. Hal itu pulalah yang dirasa turut mempengaruhi arah pemberitaan TJP yang cenderung netral dan tidak memojokkan satu pihak tertentu. Koran ini ingin tetap mempertahankan citra sebagai koran bagi ekspatriat yang tidak terlalu keras mengritik pemerintah. Namun, tanpa disadari, hal itu juga yang membuat fungsi pemberitaan tidak berjalan dengan kritis. Ketika harusnya mereka bisa menyampaikan kritik terhadap pemerintah, namun mereka memilih untuk berpihak pada kepentingan komersial yakni mempertahankan pembaca.

Mengambil contoh pada peristiwa liputan kampanye pilpres 2009 silam, bahwa partai besar akan menarik massa besar, dan dengan demikian akan menjadi berita yang menarik pula. Tetapi ketika sudah di tingkat institusi, persoalannya tidak lagi semudah mencari partai yang melakukan kampanye besar-besaran. Walaupun fotografer dan redaktur memiliki idealisme mana foto yang bagus dan memenuhi standar jurnalisme serta fotografi, tetapi ketika atasan tidak mengizinkan, maka foto yang sudah dipilih itu harus diganti dengan yang lain. Ditolaknya foto itu bisa dikarenakan alasan pragmatis, yakni kepentingan komersial saja.

\section{Negosiasi Foto "Jurnalisme Pesanan"}

Kurator foto Oscar Matullah senantiasa mengingatkan bahwa "agama" seorang fotografer jurnalisik adalah profesionalitas, sehingga secara menyeluruh dedikasi dan intelektualitas menjadi poin penting. Fotografer jurnalis sebaiknya mampu memahami komentar dan berbagai persoalan yang ada diliput sebagai data yang independen. Ideologi yang mereka pegang sebaiknya memihak pada masyarakat umum. Seorang fotografer tidak lain merupakan perantara yang menyuarakan kepentingan publik, khususnya pada saat masyarakat harus berhadapan dengan penguasa.

Pada kenyataan riil di lapangan sebuah pemberitaan, terutama foto jurnalistik, menjadi hal yang sangat memprihatinkan jika telah luntur etika dan moralitas insan media. Hal ini dapat terjadi jika idealisme para fotografer menjadi menipis dikarenakan tuntutan finansial yang kurang memadai di masing-masing institusi. Oleh karenanya, tidak jarang foto dalam peristiwa kampanye pilpres yang lalu terlihat sebagai "pesanan" dari pihak tertentu yang berafiliasi dengan media bersangkutan. Dari sanalah muncul anggapan bahwa fotografer serta jurnalis bisa "dipesan" untuk melayani kepentingan pencitraan pihak-pihak tertentu. Dalam sesi FGD tanggal 5 Agustus di kantor berita Antara, Andre menyatakan:

"Pemred dan managing editor pasti meminta semua foto yang ada. Kita tunjukkan frame yang sekiranya cocok untuk institusi. Untuk foto-foto yang subjektif atau pribadi di-keep.

Meskipun fotografer bisa mendapatkan gambar atau foto yang menarik serta memiliki nilai berita di lapangan, namun foto tersebut tidak serta merta bisa naik cetak. Ada kuasa dari pemimpin redaksi dan editor pelaksana yang akan meminta semua foto hari itu untuk kemudian diseleksi frame yang cocok dengan institusi. Fotografer tentu tidak bisa protes begitu saja ketika foto mereka tidak dimuat, karena mereka bekerja di bawah institusi yang juga diselimuti dengan berbagai kepentingan, terutama kepentingan modal. Jika fotografer tetap bersikeras dengan frame yang telah mereka ambil, bisa jadi mereka akan mendapat sanksi dari kantor dan kehilangan pekerjaan mereka. Halhal seperti itulah yang kemudian membuat citra jurnalis dan fotografer lekat dengan kata "pesanan".

Dalam tekanan kelangsungan hidup media yang berat di satu sisi, dan dalam dunia yang berubah menjadi lebih pragmatis, serta kompetisi yang semakin ketat antarmedia, maka media perlahan kehilangan si- 
fat "independennya". Media hidup dari pesanan-pesanan dan dari hal-hal yang sederhana berupa iklan hingga pesanan nilai, dan kepentingan yang diusung oleh hadirnya suatu surat kabar.

Dalam contoh kasus pemilihan presiden 2009, foto jurnalistik telah dimanfaatkan secara intensif oleh ketiga calon presiden dan wakil presiden. Foto-foto calon tidak hanya ditampilkan apa adanya dalam surat kabar, tetapi juga dikomposisikan sesuai dengan tujuan dan citra yang ingin dibangun atas kehadiran seorang tokoh. Dalam berbagai foto tampak bahwa usaha mencapai tujuan-tujuan politik cenderung dilakukan dengan memanfaatkan simbol-simbol yang mudah dipahami oleh publik, seperti simbol agama, etnis, dan kelas sosial.

Foto kampanye pemilihan presiden bisa dilihat sebagai sebuah pertunjukan (performance) drama sosial dalam kehidupan sehari-hari. Sebagaimana dikatakan Schechner, bahwa politisi, aktivis, pengacara, bahkan teroris menggunakan teknik-teknik performance (memakai panggung atau podium, cara berbicara, menyapa audiens, cara berdiri, memakai setting tertentu) dengan tujuan untuk mendukung tindakan mereka. Ia menyatakan:

The politician, activist, lawyer, or terrorist all use techniques of performance - staging, ways of adressing various audiences, setting, etc. - to present, demonstrate, protest, or support spesific social actions (Schechner, 2002: 68).

Hal tersebut dapat dianalogikan bahwa politisi merupakan aktor yang bermain dalam panggung sosial drama. Tindakantindakan mereka dalam kampanye pemilihan presiden berperan aktif dalam pembentukan konstruksi realitas atas citra diri mere$\mathrm{ka}$, yang dibekukan melalui still image oleh praktisi media untuk tujuan pemberitaan. Foto yang dimuat di media massa merupakan bentuk visual culture yang dapat dibaca melalui berbagai perspektif termasuk dalam konteks ini adalah perspektif budaya visual. Membaca foto sebagai still image yang merekam kegiatan politik melalui budaya visual dapat dilakukan salah satunya de- ngan melihat representasi positif atau negatif.

Membaca foto berarti melihat perbedaan image serta fungsi ideologi, media dan budaya mereproduksi dominasi sosial dan diskriminasi (Van der Veer, 2000). Dalam konteks ini, dapat dimengerti bahwa performance dalam perspektif politik dapat dilihat dari empat dimensi. Pertama, menyangkut hubungannya dengan kekuasaan. Kedua, menyangkut hubungan antara performance dengan ideologi, yaitu ba-gaimana performance mereproduksi, memungkinkan, melanjutkan, menantang, menentang, mengritik dan menetralkan ideologi. Ketiga, menyangkut hubungan performance dengan hegemoni yaitu bagaimana pertunjukan secara simultan mereproduksi dan meresistensi atau menolak hegemoni. Keempat, menyangkut hubungan pertunjukan dengan dominasi, yaitu bagaimana performance mengakomodasi dan mengontestasi dominasi (Conquergood, 2003: 19).

Kampanye pemilihan presiden sebagai sebuah realitas sosial yang mewujud dalam drama sosial merupakan sebuah bentuk performance. Realitas tersebut mengalami transformasi tingkat pertama yang mewujud dalam sebuah performance. Kemudian, performance tersebut mengalami transformasi tingkat kedua dan mewujud dalam karya sebuah foto. Ada transformasi realitas ke dalam sebuah performance atau drama sosial yang kemudian mengalami transformasi pada tingkat selanjutnya dalam bingkai foto.

\section{Mekanisme Pemberitaan Foto Jurnalistik di Media}

Mekanisme yang dimaksudkan di sini adalah suatu bentuk proses, prosedur, atau metode pemberitaan dari media yang digunakan sebagai standardisasi sistem pemberitaan itu sendiri. Sejalan dengan teori yang dikemukakan oleh Brian McNair (1994: 39-58) terdapat tiga pendekatan yang menjelaskan isi media yang merupakan substansi berita. Pertama, pendekatan ekonomipolitik, yang berpendapat bahwa isi media 
lebih ditentukan oleh kekuatan ekonomi dan politik. Mekanisme produksi media dilihat sebagai bagian integral dari relasi ekonomi dan struktur produksi sehingga pola dan jenis pemberitaan ditentukan oleh kekuatan ekonomi yang dominan dalam media.

Kedua, pendekatan organisasi. Melihat pengelola media sebagai pihak yang aktif dalam proses pembentukan dan produksi berita. Berita dilihat sebagai hasil dari mekanisme yang ada dalam ruang redaksi. Dalam hal ini maka kerangka ideologis redaktur menjadi salah satu faktor penentu dari kualitas pemberitaan, yang berkaitan dengan kebenaran dan kebijakan check and balances dari berita. Dengan kata lain, produksi berita adalah mekanisme keredaksian semata, setiap organisasi berita mempunyai pola dan mekanisme sendiri untuk memberitakan suatu peristiwa. Mekanisme itu bersifat internal dan tidak ditentukan oleh kekuatan di luar media. Media dianggap otonom dalam menentukan apa yang boleh atau tidak boleh, buruk atau tidak buruk, dan layak atau tidak layak untuk diberitakan.

Kecenderungan ini berbeda dengan mekanisme pemberitaan oleh media-media di Indonesia yang juga mempertimbangkan kekuatan dari luar seperti segmen pasar dan cara mempertahankan diri di dunia media agar tetap survive dan establish seperti yang diungkapkan oleh redaktur Kompas pada 18 September 2010 sebagai berikut:

"Untuk bisa seperti sekarang ini, penggunaan bahasa dan cara yang lebih santun dan tidak radikal menjadi pilihan oleh para redaktur di media tersebut..."

Ketiga, pendekatan kultural. Proses produksi berita dilihat sebagai mekanisme yang rumit dan lebih melibatkan faktor internal media (rutinitas organisasi media) sekaligus juga faktor eksternal di luar media. Mekanisme yang rumit itu ditunjukkan dengan bagaimana meliput sebuah peristiwa dalam pemberitaan harus melalui perdebatan sengit di ruang redaktur, di samping terdapatnya pengaruh ekonomi-politik di luar media yang tidak bisa dianggap re- meh begitu saja. Masing-masing media memiliki sistem dan mekanisme pemberitaannya sendiri.

Mekanisme pemberitaan dalam Koran Tempo dapat dijadikan contoh di sini. Cara kerja bagian foto di Koran Tempo adalah: pertama, fotografer memotret berdasarkan penugasan yang diberikan oleh Koordinator Foto Tempo News Room (TNR) atau dari periset foto yang mengerjakan sesuai dengan rubrik atau halaman bidang yang dikerjakan. Kedua, prosesnya bisa saja redaktur halaman atau reporter yang mengerjakan rubrik tertentu meminta foto untuk kepentingan halaman atau tulisannya lalu meminta fotografer ke redaktur foto koran, koordinator foto TNR atau periset foto. Ketiga, yang berhak membagi penugasan adalah koordinator foto, karena dia yang paling tahu siapa saja fotografer yang bertugas pada hari itu. Periset foto memberikan daftar yang harus difoto ke koordinator foto. Keempat, periset foto di Koran Tempo memegang beberapa halaman dan rubrik tertentu yang tugasnya mencari foto yang sesuai yang dibutuhkan pada hari itu untuk penerbitan besok. Kelima, periset foto, koordinator foto, atau redaktur foto wajib memberikan informasi yang diperlukan fotografer agar memotret sesuai dengan yang diperlukan. Jika memungkinkan diberi konsep pemotretan untuk rubrik-rubrik tertentu. Keenam, redaktur foto yang bertugas selain memegang beberapa halaman juga bertanggung jawab atas foto halaman satu dan quality control pada semua foto yang tampil di koran.

Di samping foto pesanan, terdapat proses lain yang dapat dipaparkan sebagai berikut: Pertama, perencanaan dibuat pada malam hari berdasarkan perencanaan liputan untuk besok atau berdasarkan undangan yang diterima redaksi. Penugasan dan undangan dipilih sesuai dengan kebutuhan, nilai beritanya, serta kemungkinan mendapatkan visual yang menarik. Informasi itu bisa juga inisiatif dari fotografernya sendiri untuk meliput berita. Kedua, malam itu penugasan diberikan kepada fotografer. Ke- 
tiga, pada rapat perencanaan pagi, rencana dimatangkan lagi, mana yang akan dimuat di berita utama, halaman depan atau halaman dalam. Jika ada perkembangan baru maka petugas piket dari bagian foto menginformasikan kepada koordinator foto TNR untuk menugaskan fotografer untuk meliput. Keempat, tidak menutup kemungkinan setiap saat penugasan bisa berubah sesuai dinamika berita yang terjadi saat itu. Keli$m a$, fotografer yang meliput mengirimkan foto by email, kemudian dimasukkan ke jaringan intranet agar bisa diakses oleh semua pengguna di Tempo. Tentu saja setelah diedit oleh koordinator foto atau petugas piket. Keenam, pada rapat sore dilakukan pemilihan berita mana yang untuk halaman depan dan mana yang dalam. Bagian foto menawarkan foto-foto yang diperoleh saat itu. Jika visualisasi yang ditampilkan bukan dalam bentuk foto utuh, misalnya ilustrasi atau infografis, maka redaktur foto harus menyiapkan foto-foto yang dibutuhkan untuk melengkapinya. Ketujuh, redaktur foto dan periset memeriksa foto dan keterangan foto apakah sudah sesuai dengan halamannya.

Untuk kriteria foto layak di Tempo sebetulnya sama dengan kriteria penilaian fotojurnalistik pada umumnya: tentu saja foto harus mempunyai nilai berita yang tinggi disertai dengan kualitas fotografis yang bagus, misalnya komposisi, teknis fotografi, ketajaman, pencahayaan dan sebagainya. Jika secara kualitas kurang baik, setidaknya nilai berita yang tinggi dan eksklusif menjadi pilihan utama untuk dimuat. Foto yang baik juga jika keterangan fotonya lengkap. Jika tidak, maka foto itu tidak akan dimuat karena rawan kesalahan (Hasil wawancara dengan redaktur foto Tempo tanggal $22 \mathrm{Sep}$ tember 2010).

Terlepas dari kualitas dan standar foto secara teknis, berbagai aspek muncul dalam proses produksi foto hingga dilansirnya sebuah pemberitaan foto jurnalistik. Jiwa dan ideologi serta platform dari suatu koran sangat menentukan foto yang nantinya akan dipilih oleh redaktur untuk dimuat. Aspek pemihakan dan kepentingan-kepentingan merupakan suatu yang terlibat dengan jelas, otoritas individu dalam tim redaksi hadir tidak begitu tegas dibandingkan otoritas lembaga tempat mereka bekerja. Jika merujuk pada model framing Zhongdag Pan dan Gerald M. Kosicki, model ini berkaitan dengan pertama, sintaksis yaitu cara penyusunan berita yang pada dasarnya di masing-masing media memiliki kemiripan proses penyusunan berita. Kedua, skrip yaitu cara mengisahkan fakta $(5 \mathrm{~W}, 1 \mathrm{H})$ pada tahap ini pun semua insan pers juga melakukannnya dengan memperhitungkan unsur $5 \mathrm{~W}, 1 \mathrm{H}$ baik itu dalam pembuatan caption untuk foto maupun penulisan berita; Ketiga, tematik yaitu berkaitan dengan cara penulisan atau perekaman fakta; penulisan dan perekaman fakta ini memiliki prinsip dasar yang kuat sesuai dengan kode etik yang ada serta ketentuan dari media masing-masing. Ada semacam standardisasi dari masing-masing industri media. Keempat, retoris yaitu cara menekankan fakta. Dalam hal cara menekankan fakta, mereka cenderung memakai platform yang dimiliki masing-masing media. Analisis framing dalam hal ini merupakan suatu pendekatan di dalam pengelolaan data untuk menghasilkan suatu pemahaman yang lebih tajam atas data.

\section{SIMPULAN}

Kecenderungan pemanfaatan media oleh partai-partai politik atau tokoh-tokoh politik dalam rangka pemenangan suatu pemilihan ditentukan oleh perubahan sistem politik yang bersifat desentralistik, yang karenanya dibutuhkan satu mode komunikasi yang lebih penetratif dengan masyarakat. Pemanfaatan media untuk tujuantujuan politik kemudian melahirkan dilemadilema tersendiri. Telah terbina satu jalinan kerjasama antara media dengan negara dan pasar, karena proses politik tidak hanya merupakan sebuah kegiatan negara tetapi juga merupakan kegiatan yang melibatkan stakeholders, seperti pasar dengan orientasi komersialnya. 
Dalam proses semacam ini, tampak bahwa idealisme media dengan segala pilihan nilainya mulai tergadaikan. Media tidak bisa mengisolasi dirinya dari perkembanganperkembangan kapitalisme yang berlangsung di Indonesia yang tantangan media untuk survive menjadi semakin besar. Dalam konteks semacam ini, tidak jarang terjadi media menjadi alat propaganda politik tokoh-tokoh dan partai-partai politik. Fungsi edukasi publik seringkali terabaikan dalam peran media terhadap kelembagaan pers dan masyarakat.

Foto jurnalistik dalam hubungannya dengan media tersebut telah menjadi hal penting untuk mencapai tujuan-tujuan politik dalam satu pemilihan khususnya calon presiden. Foto jurnalistik tidak hanya memiliki kemampuan untuk mengkomunikasikan nilai-nilai tentang tokoh atau partai, tetapi juga memadatkan serangkaian pesan yang dapat dibaca oleh publik tentang tokoh yang terlibat di dalam pemilu. Hal ini disebabkan oleh kemampuan fotografi di dalam mewakili begitu banyak nilai dan pesan sekaligus secara persuasif.

Foto dalam media cetak, dengan demikian, selain telah dibingkai oleh frame yang diciptakan fotografer, juga dibingkai dengan sebuah konteks yang akan mengarahkan pembaca pada maksud yang dituju oleh media. Hal tersebut sejalan dengan proses kontruksi realitas dalam media, media merupakan faktor eksternal yang akan mempengaruhi pemikiran pembaca atas hal-hal yang diberitakan.

Fotografer dan tim redaksi dapat dikatakan sejajar dengan peran kurator pada seni rupa. Merekalah yang menciptakan konsep dan tema yang akan ditampilkan pada pembaca, yang pada puncaknya turut berpengaruh terhadap foto yang ditampilkan di media yang bersangkutan. Kedudukan dan fungsi foto kemudian ditentukan oleh bagaimana kurator mendefinisikan foto untuk ditampilkan.

Dengan demikian, meskipun kerja fotografer berbasis pada teknik dan kreativitas, namun fotografer jurnalistik memiliki basis kreativitas yang berbeda dengan fo- tografer seni. Pada diri fotografer jurnalistik, kreativitas mereka ditentukan oleh pasar (market based orientation). Hal-hal seperti permintaan pasar, berita seperti apa yang akan menarik minat pembaca, akan berpengaruh terhadap ideologi media bersangkutan, dan pada akhirnya akan berimbas pada gambar yang dihasilkan oleh fotografer. Walaupun dipengaruhi pasar, namun fotografer jurnalistik tidak sepenuhnya kehilangan kreativitas. Ia akan melakukan kompromi dengan tujuan agar 'membentuk' pasar yang akan memakai karya fotonya. Kompromi tersebut misalnya dengan sinkronisasi idealisme yang dimiliki dengan kepentingan dan atau permintaan pasar.

\section{DAFTAR PUSTAKA}

Bourdieu, P., (ed.), 1977, Algérie 60, Paris: Les Editions de Minuit.

1992, An Invitation to Reflexive Sociology, Chicago: University of Chicago Press.

- 1995, Outline of a Theory of Practice, Cambridge: Cambridge University Press.

Conquergood, D., 1991, "Rethinking Ethnography: Towards a Critical Cultural Politics", Communication Monographs 58, 179-194.

McNair, B., 1994, News and Journalism in the UK: A Textbook, London and New York: Routledge.

Schechner, R., 2003, Performance Studies: An Introduction, London: Routledge.

, 2003, Performance Theory, London: Routledge.

Van der Veer, R dan Valsiner, J., 2000, The social mind: Development of the idea, Cambridge, MA: Cambridge University Press.

Yuniar, R., 2009, "Representasi foto jurnalistik kampanye Pilpres 2009" dalam Irwan Abdullah et al. (ed.), Dinamika Masyarakat dan Kebudayaan Kontempo- 
Ririt Yuniar, Irwan Abdullah, Timbul Haryono, dan G.R. Lono Lastoro Simatupang -- Kode Etik Jurnalistik dalam Praktek Foto-Jurnalisme: Kasus Kampanye Pemilihan Presiden 2009 di Indonesia

rer, Yogyakarta: Tici Publications \& Pustaka Pelajar.

, 2009, “Otentisitas dan Manipulasi dalam Dunia Fotografi: Suatu Analisis Ruang dan Waktu", Timbul Haryono et al. (ed.), Seni dalam Bentuk, Ruang dan Waktu, Jakarta: Wedatama Widya Sastra. 